\title{
1 Strategic reflexivity in linking gender equality with sustainable energy
}

\author{
An engineer in the gender profession
}

\author{
By Rebecca Elmhirst and Bernadette P. Resurrección \\ In conversation with Joy Clancy
}

\begin{abstract}
Recent debates about climate change have prompted a renewed emphasis on the relationship between energy and development, moving discussion away from preoccupation with energy resource scarcity and bringing instead a focus on pathways to transition to low carbon alternatives (Leach et al., 2010). At the same time, there has been a growing recognition that far from being simply a technological and economic phenomenon, energy is social in its organisation, assembled at scales from individual to planetary (Miller et al., 2015). Questions about gender inequality - in terms of access to energy and the power to engage in energy decision-making at different scales - are long-standing in development contexts as they are in the realms of agriculture, forestry and water (Cecelski, 1995). The mission of the gender expert is to address energy security and energy justice from a feminist perspective. However, the role of gender expertise in the context of energy systems brings with it its specific challenges that relate to its embeddedness in the design and operation of technological systems, and in particular, in engineering: a field which has historically lacked gender diversity and which workplace sociologies have identified as being heavily masculinised across almost all contexts (Pearl-Martinez and Stephens 2016).
\end{abstract}

In this chapter, we focus on the voice and experience of energy engineer Joy Clancy, a leading advocate in the area of energy and gender, particularly through her role as a founder-member of ENERGIA: the International Network on Gender and Sustainable Energy (ENERGIA, 2015). We consider her reflections and insights through the lens of recent feminist work in science, technology and society (Jasanoff, 2004; Haraway, 1988) and the sociology of expertise (Azocar and Marx-Ferree 2016) to explore obstacles and opportunities for addressing vital gender concerns in energy policy, institutions and technologies. The chapter is organised around three points of focus that emerged in our conversations: (i) how expertise is produced and made effective via a personal feminist politics and a professional identity as an engineer; (ii) strategic reflexivity in connecting engineering science and gender analysis in order to enhance the sustainable development, delivery and use of energy; and (iii) a reflection on pragmatism in a context 
where the performativity of numbers and 'equality as efficiency' arguments are used to construct a common language between different actors in the genderenergy-development policy nexus. We begin with a brief overview of the context of energy, gender and development, how this field emerged from the energy crises of the 1970s, and the renewed impetus around gender concerns that have gathered in relation to the Sustainable Development Goals and international strategies to address climate change through a transition to low carbon energy provision.

\section{An evolving field: gender issues in energy systems}

The context for Joy Clancy's work on gender and energy began during a period marked by crises in energy supply: the geopolitical dynamics of access to oil reserves for countries of the global North, and fuelwood shortages in the global South. Her professional pathway, which she discusses in the next section, began with a focus on small-scale alternative technologies directed towards resolving the need for fuelwood, but has gone on to reflect what Danielsen (2012) characterises as a series of phases of gender, energy and development, including: (i) the crisis in biomass degradation that affected women's fuelwood collection and cooking (1970s to 1980s); (ii) concerns over the health and workload burdens associated with fuelwood or biomass-based household energy use (1980s to 1990s); (iii) energy poverty in the context of livelihoods and gendered rights to the assets required to access energy services (1990s to early 2000s); and (iv) energy futures, renewables and climate change with new technologies, new forms of organisation of supply and liberalised energy markets (2000s) (Clancy 2016).

In the poorest developing countries in Africa and Asia, as much as 90 per cent of total energy consumption has been attributed to households and consisted of traditional biomass fuels mostly managed and collected by rural women, and this prompted a focus on women's roles and energy use within the household as an entry point for 'gender and energy' (Cecelski \& Dutta, 2011). Subsequently, the emphasis for development policy and practice shifted towards examining health and wellbeing impacts for women and children: many of the biomass stoves traditionally used have been identified as a key source of indoor air pollution, while collection of biomass also caused health problems and placed women in circumstances where they were subject to physical and sexual abuse (Clancy et al., 2002). By focusing on the reproductive role and labour of women as users of energy for household food provision, researchers revealed that without access to modern energy services, women and girls spend most of their day performing basic subsistence and caring obligations, including the physically draining task of collecting biomass fuels. Findings such as these established a gender research niche within energy and development studies directed towards improved cook stove development, design, and likely adoption by women (Kelkar \& Nathan, 2005), and on the diffusion of alternative technologies among rural households. This was Joy's entry point into this field.

Chiming with an emphasis in gender and development research and practice on gender as relational (Rathgeber, 1990), work has gone on to show how access 
to energy is determined by intra-household decision-making and by the undervaluing of women's labour and their low opportunity costs, as well as women's relative social position (Lambrou \& Piana, 2006; Cecelski \& CRGGE, 2006; Cecelski, 2004). Although the number of people without access to electricity has fallen in recent years, gendered energy poverty remains, with variability in the quality and affordability of energy supply and grid connection. This is attributed to the ways that other aspects of gender inequality intersect with energy access: around women's low levels of property ownership, access to bank accounts, low incomes and lack of official documentation that lead to gendered exclusions. The wider significance of such exclusions for development and for women's economic and political empowerment were identified as gender and energy researchers demonstrated the importance of other forms of energy access for women, such as process heat for small-scale income generation (de Groot et al., 2017) and mechanical energy to reduce drudgery of water collection, food processing and laundry (Kooijman et al., 2018).

Joy acknowledges that the energy sector has lagged behind others (e.g. agriculture, health) in terms of engaging with the gender agenda. Her work with ENERGIA has persistently pushed for gender issues to be raised, and in recent years this has gained greater traction as the recent United Nations (UN) Sustainable Energy for All (SE4All) and the UN Sustainable Development Goals have drawn attention to gender and energy linkages. The development of alternative energy sources and the creation of carbon markets to mitigate climate change and reduce fossil fuel dependency (Rojas et al., 2014; Gay-Antaki, 2016; Nelson \& Kuriakose, 2017) requires broader attention to gender within energy systems and throughout the supply chain, and a recalibration of the balance between technical (engineering), economic (pricing and cost-benefit analysis) and social domains to reflect how social, economic and political dynamics are linked to the design and operation of technological systems (Jasanoff, 2004). As Joy puts it, energy transition is not solely about the source of energy or a shift away from fossil fuels. Other transformations are also apparent, as energy infrastructures for production and storage are scaled down and decentralised within renewable energy systems. This provides a new entry point for gender concerns as social considerations are elevated around whose preferences are implemented into policy (Miller et al., 2015).

In the remainder of this chapter, we discuss Joy's experience and reflections about energy studies, the dominance of engineering and technical fields and the place of 'gender expertise' amidst this. We consider Joy's approach towards persuading the unconvinced coupled with her desire to build an evidence base for policy, and the pragmatics of 'efficiency' and 'numbers' as credible frames and forms of knowledge within gender and energy work.

\section{Engineering expertise and feminist politics}

In our conversations with Joy, we were interested in exploring her personal biography, from starting out as a chemist to becoming a leading energy and gender proponent, and the difference her technical background has made in the kinds 
of collaborative work that she has gone on to do. Joy's work involves bridging between the technical and social (gender) dimensions of energy systems, and her story is one in which 'gender expertise' is made effective via her professional identity as a trained engineer. Joy notes that her entry into chemistry as an undergraduate in the late 1960s was somewhat accidental and perhaps a reflection of early efforts to encourage more participation of women in a male dominated field. Her interest in energy began at Reading University in 1980, where she was doing a $\mathrm{PhD}$ and looking for an area of research to focus on: at this point she began her work on small-scale (appropriate) technologies and alternative energy systems, looking at replacing wood fuel with biogas to power cookstoves in the global South. This work was linked to the E.F. Schumacher inspired Intermediate Technology Development Group (ITDG) (which was renamed Practical Action in 2005) (Practical Action, n.d.). The framing of the problem was technical, rather than social, the expertise required was the design and engineering of an appropriate technology. Having not started out as a 'gender professional' and with no academic background in social science, Joy's interest came more from trying to make sense of the responses of 'beneficiaries' to the appropriate energy technologies being offered to them.

Joy: I did technology. That was it. But in my personal life, I was, of course, very radical as a feminist! They were two separate parallel worlds and it took quite some time for me to wake up and think, 'Oh, dear. Those ladies carrying the fuelwood are not taking up my nice biogas system for a lot of complicated reasons that your feminism should have enabled you to see!'

The context of engineering is important for understanding gender and 'expertise'. As Miller et al. (2015) note, the dominant approach to energy systems has been influenced by technical knowledge and capacities rooted in the professional field of engineering. Historically, engineering design was a process of trial and errorthe word engineer is derived from the Latin ingeniator, meaning someone who is ingenious - but since its professionalisation in the $19^{\text {th }}$ century, it has shifted towards being a white collar mathematics and science-based field of endeavour (Mills et al. 2014). Much has been made of the gender inequalities inherent in the engineering profession more broadly, which are related to the field's hegemonic masculinity (Connell, 2016): an area of expertise occupied by men's bodies and masculine practices which normalises male advantage (Faulkner, 2009a; 2009b; Kronsell, 2011; Liebrand, 2014). For women working in a male-dominated profession, this can mean both their subtle exclusion and their hyper-visibility, with women engineers adopting strategies to be one of the men and fit in, or to benefit from standing out as a woman (Ettinger et al., 2019). However, having legitimated expertise (i.e. professional qualification) in engineering offers advantages: sociologists note how credentialist ideologies connect specific forms of expertise to claims of authority and professional boundary marking (Saks, 2012). This is something that Joy concurs with: she finds that having a technical background in science and engineering means that technical people will listen to her, she can 
establish common ground and 'fit in'. Once she tells a technical audience that she has a $\mathrm{PhD}$ in engineering, she can feel that people in the room begin to relax because they feel that 'here's a person who understands me'.

Joy: When I was offered the professorial chair in the university, the Dean wanted the title to be 'professor in gender and energy' and I said no, I want it as 'energy and gender' because if I put it the other way around, the majority of technical people will switch off. And it's a much better, stronger way of engaging with people and getting people to listen to what I want them to hear. Whereas if I put it the other way around, all the converted like the Babettes and Beckys will listen, but you don't get the sceptics to be convinced to listen to you.

Outside the University, some of the organisations with which Joy now works (for example, Africa Biogas, HiVOS (People Unlimited) and SNV (Netherlands Development Cooperation) are heavily dominated by male engineers. She believes that her technical background enables her to mix more easily in these circles, giving her a way in for introducing the role of women and/or gender in energy advocacy and research.

Joy: I'm really quite pragmatic in the sense of not profiling myself too much as a gender expert because in some ways it becomes a barrier since there's a lot of misunderstanding about what gender is about. Many think it's all about counting women. A lot of gender mainstreaming merely involves counting bodies and is not about changing values regarding inequality. I'm also not a social scientist so I cannot say that I'm a gender professional. I don't have a theoretical background in gender and feminist studies. My feminism comes from my political activism.

Eyben and Turquet (2013) note that feminists working in development organisations constantly have to make a difficult balancing act, and this is similar to what Joy alludes to in discussing her university and energy sector experience. But for Joy, it is clear that we (i.e. those working as 'gender experts') need to be conscious of how others perceive us as gender professionals or feminists. Avoiding this label may be one way of preventing them from 'switching off' at the first instance as this does not help realise our feminist goals of equality.

Joy's experience also points to the importance of recognising the dynamic, intersecting and open-ended character of how expertise is enacted and recognised in energy and gender work. Taking a lead from science and technology studies (STS) scholars and sociologists, 'expertise is a constantly changing legitimation of actions', and attention should be directed to the 'material and discursive conditions under which expertise itself is created and disseminated into a network' (Azocar and Ferree, 2016: 1084; Latour, 1987). Put another way, whilst it is helpful to understand the context of engineering as an expert field in order to reflect on openings for tackling gender inequality, it is also crucial to recognise the diversity and fluidity of that context and its framings. 
As was noted by a contributor to Eyben and Turquet (2013: 61), '...you can become so entrenched in your identity as an activist against a dominant structure that you don't see the opportunities. You're just painting an entire field of people of a particular color... maybe that's why a lot people are turned off by feminism, because it's become reified in some way'.

Joy: It is quite important not to homogenise the world outside the 'gender profession' as my experience has shown me that it's very diverse out there [a point made by Faulkner, 2009a:172].

Joy locates this diversity in her own professional network in the history of intermediate (appropriate) technology (Milner, 2017), which was ascendant at the time when Joy was undertaking her $\mathrm{PhD}$ (Practical Action, n.d.). The network of engineers she was working with were part of the environmental movement and supported the idea that the entry point of appropriate technology was not only about the technology, but about people as well. Thus, the dualism between the technical and the social, which some sociologists of engineering have pointed out, was less pronounced. Furthermore, Joy's reflection is that the professional network of alternative energy engineers working in development contexts has meant she has worked with men who were supportive of her work around social and gender issues, and less aggressively masculinist, which made navigating the field of energy and gender much easier. The advantage, she says, lies in having mentors and a support network in an environment where your views (on gender, for example) don't easily fit.

\section{Relating with the unconvinced: the ENERGIA network}

The formation of ENERGIA, a network linking people from different disciplinary and professional backgrounds who had a shared interest in addressing the gender, development and energy nexus, is illustrative of an effort to bridge an epistemological gap between social and technical sciences, materialising a particular form of networked expertise (Azocar and Ferree, 2016). Joy illustrates the gap that existed prior to the founding of ENERGIA by noting that at the United Nations Beijing World Women's Conference in 1995, access to energy was not seen as a basic need so there was no UN agenda for it, and instead, it was subsumed under 'environment': a context which positioned women as managers and users of natural resources such as fuel wood. A paper was published in the influential journal Energy Policy by the Elizabeth Cecelski, a sociologist, based on her experiences at the International Labour Organization, that looked beyond the woodfuel crisis and improved stoves to focus instead on a broad range of issues around women's work, energy pricing and access, transport and modern energy forms (Cecelski, 1995). However, Joy notes that policy makers were not picking up the connection between gender and development and demand-side issues in the energy sector, and this lack of awareness is what prompted her to bring her engineering expertise into collaboration with Elizabeth Cecelski's social science expertise. Along 
with others, they went on to found ENERGIA. They diagnosed the problem as one of a limited evidence base that would enable them to broaden the debate, and they set out to address this, whilst at the same time, creating a 'space' to engage with policy makers. Whilst ENERGIA has gone on to be a leading organisation for research and advocacy in this area, we turn our attention to the 'small wins' that come about through Joy's attempts at bridging between different communities: engineers, policy makers, academics, private sector energy companies, and academic 'gender work'.

From the start, the approach has been pragmatic, with an emphasis on working in partnership for women's empowerment, gender and energy research, and gender and energy advocacy. Whilst there is an international secretariat based in the Netherlands, the network links 38 partners from across 18 countries, predominantly, but not exclusively in the South, working on projects, programmes and policies that explicitly address gender and energy issues. ENERGIA also creates training modules and tools for the energy sector, for example, on gender audits, to connect local initiatives across different contexts. Joy notes that there are challenges of bringing a gender perspective into play whilst connecting and working across different types of expertise.

What have been the strategies that have led to successes in research and policy advocacy within ENERGIA? For a start, Joy points to the importance of 'finding the right ear'.

Joy: I recognise that I am using my privilege at times and try to avoid speaking on behalf of women in the South, and also of creating new 'gender myths'.

For this reason, Joy (and Elizabeth Cecelski) have withdrawn to an advisory capacity although of late they have both become active in ENERGIA's research programme. The network is dominated by the global South, with Sheila Oparaocha as International Coordinator and Programme Manager of ENERGIA. From her own experience with ENERGIA, Joy makes the point that it is important to avoid making assumptions in either direction when working across disciplines and professions within gender training and advocacy networks.

Joy: For example, with the Africa Biogas Partnership Programme, which is very engineering-led. Initially there was resistance from the engineers to train women as brick workers, because this involved a change in women's roles and gender norms. I interviewed people from SNV [the NGO leading the programme] who admitted being taken aback that once trained, women were able to do this work [and that this was acceptable]. I find avoiding assumptions does work. And because I understand how the system works, the engineers are more accepting.

I don't disguise the fact that I'm interested in gender, and I try to encourage the idea that gender is relational and that we shouldn't push men out of the picture. A piece of work that I did for the European Commission a number of years ago was to show to the men who were working in the Commission 
that if they actually were much more gender sensitive or gender aware in their working environment, then it would also be for their betterment in the long run. I also said the same thing on a project with the Botswana Power Corporation telling company employees that gender equality is not only good for women, but that gender transformation is about transforming everybody's lives. And I think that then gets a much better buy-in. I'm not saying though that by saying these, there is absolutely no resistance.

Joy notes that some of the best 'wins' come when there are more men making the case for gender equality in energy systems. Within ENERGIA, she notes the work of Louis Seck, Energy 4 Impact Senegal Country and Project Manager, and describes how his leadership as an advocate for gender and energy has meant there is much better gender inclusivity in Senegal's renewable energy sector than there might otherwise have been.

\section{Finding a common language: equality as efficiency and the power of numbers}

Joy's pragmatism also echoes an approach that is common among gender professionals and bureaucrats, whereby the case for gender equality is made through an argument of the gains this brings for the economy: higher economic growth, better corporate performance and achievement of development goals. A longstanding literature explores how this is partly a response to the constricted spaces within which feminists in organisations must operate; this situation creates an imperative to articulate gender equality through a language that is familiar and widely accepted (Razavi, 1997; Eyben, 2010). The seductions of this approach are not without problems, including the instrumentalisation of gender to serve ends that are far from a transformation of women's experience (Caglar et al., 2013; Sandler and Rao, 2012; Kabeer, 2016; Razavi, 2017). What does this look like in the energy sector? Joy agrees that the 'efficiency argument' is what gains acceptance and significant traction.

Babette: There seems to be more and more attention being given now to gender and energy issues compared to, let's say, 10 years ago. You've been in the sector for a fairly long time, Joy, isn't there more attention to energy justice, women as untapped talent, and making the business case out of gender equality in the energy sector?

Joy: The Sustainable Development Goals (SDGs) now offer a leverage point, since they have established an 'energy' goal. The World Bank's women's economic empowerment agenda also offers a leverage point. The role of the private sector in delivering development offers an entry point. When it comes to the energy sector, there are emerging energy business models for women. However, there is little independent evaluation of this work. A focus on the economic inclusion of women may not necessarily lead to their empowerment. 
For example, empowering women to sell cook stoves. The evidence does show that women do benefit from earning an income. I'm not against that at all, but it's the kind of emphasis on where in the energy supply chain women should be or be best at. And I don't think women are necessarily better at selling things. I just think that this is the stereotypical Avon lady model of female entrepreneurship! [i.e. women selling to other women who are 'like them'] so it is the inclusion of women as salespeople.

But it is also a reproduction of gender roles, that assumes only men could do technology, and therefore, women would be better sales agents. It's true though that in some cultures where it's difficult for a female family member to enter public economic space and that becoming a sales agent might represent empowerment, but still, it reinforces the present structures that separate women from technology. And I don't think selling cook stoves is going to radicalise gender roles.

But Joy notes that empowerment and transformation do not automatically follow gender-energy interventions.

Joy: In an evaluation project that I was involved in I realised that feminists face the uncomfortable thought that other women don't necessarily want transformation. For example, Magi Matinga, in her thesis on South Africa, finds still large piles of fuel wood outside households despite easier access to LPG stoves (Matinga, 2010). And this is because, in that particular place, a woman is judged by the size of her firewood pile. She's not a good wife and mother if the pile is low. Change in gender relations take a long time. It's not quick.

I think also that renewable energy has brought some interesting things to do with the energy transformation, not only the physical way of generating energy through local energy initiatives. Energy cooperatives, for example, can open up a space for women. The engagement of women is still very small in the Netherlands. And one of the reasons is time poverty. It doesn't necessarily always mean that it has to be big companies producing energy. But then on the other hand, I do wonder if this also partly reduces the role of the state in providing for equality of services for its citizens. For instance, if I happen to live in a locality where I've got lots of enthusiastic engineers who can put up solar panels, then I'll be alright. But if I happen to be in an area with people with less access to higher education who have less access to things, even in Europe, then I do wonder about energy security. It's a very political thing (the role of the state in the provision of utilities).

Joy's reflections contribute to a wider questioning of directionality in the relationship between gender equality and economic growth. Kabeer (2016) shows that gender equality contributes to economic growth, for example, as gender parity in education can spur a diverse and vibrant labour market. However, the inverse is not true. Bringing in women to sell cookstoves in Senegal or responsibilising 
women in The Netherlands energy cooperatives will not in itself lead to gender equality.

Joy points out that there are several conditions that need to be met if women are to be empowered in the energy sector, including education, entitlement to own property in their own right, and access to credit. Social and cultural factors may hinder women's economic empowerment - for example, whether or not women are permitted by the existing social norms of a society to be employed outside the home or, if they are, whether they control the use and investment of any income they earn. In other words, it may be a dangerous assumption that women's economic empowerment will lead to gender equality. Indeed, enabling energy access may create only the conditions that enable women to perform their traditional roles as care givers more efficiently, and possibly with a greater degree of comfort, while doing little towards transforming gender inequality (Clancy, 2016).

Our conversation with Joy turns to a second strategy for finding a common language, that is, bridging social and technical knowledges with numbers, as quantitative data is used to convince, demonstrate impact and claim authority.

Joy: Well, I think that decision-makers are primarily convinced by numbers. But numbers, as we know, don't tell the whole story. And there is this very irritating bit of data that's come out with the Global Tracking Framework [which charts progress on achieving SDGs (see IEA, 2019)].

SDG 7 [To ensure access to affordable, reliable, sustainable and modern energy for all] has three targets: access to energy and clean cooking, renewable energy and energy efficiency. In other words, electricity access and surprise, surprise, cook stoves! This means applying a gender lens because of women's association with cookstoves and the importance of clean [i.e. good indoor air quality] cooking. One of the gender myths, of course, is that female-headed households are poorer. Therefore, they have less access to electricity because of the high connection cost. However, for about ten countries in the world, the data shows something completely different: the percentage of female-headed households with access to electricity is higher than male-headed households. Why? No one can answer that because the statistical data doesn't answer that sort of question.

So we're left with a blindspot. One can only uncover the causes if one does qualitative work and preferably ethnographic investigation. When I proposed a qualitative data approach to the World Bank while I was doing a consultancy with them, I was met by a kind of incredulity and questions around what a qualitative analysis would show and how would it be helpful. And I suggested to them, 'Look, you only need to ask one question to people. Do you feel since you have had access to electricity, or your cookstove, or whatever, do you feel that your life has improved or that your family's life has improved?' And it either has or it hasn't, and then you can judge whether what you're doing is a success or not. And if it's a success keep doing it, and if it isn't, then you've got to go and find out why. 'Ask one question', I said. 'People are limited to being only the judges of what is better for them. 
Because what's better for me is not necessarily better for you or for a million and one other people. It's my life that matters. It's my life that I am the best judge of'. So it is the nature of the evidence that decision-makers are prepared to accept that I find worrying.

What to do? Well, I mean, part of our gender and energy research programme is to produce some of the numbers to back up what we are saying. I think this is also useful for us in advocacy mode. You also have to find the right pitch and to say it often enough to one audience.

Metrics and quantitative impacts of a problem have taken on epistemological authority in mainstream development, particularly within traditionally technical domains such as energy. Used as evidence, statistics serve a performative function in that they can constitute the very reality in which policy makers and professionals make their interventions. For example, researchers have shown how the narrow focus on numbers can erase 'broader trajectories of socio-environmental change' from the policy domain as our knowledge of climate change impacts are directed towards specific framings (Tuana, 2013; Nightingale et al., 2019). However, there may be instances where certain kinds of quantitative instruments offer a common language and from this, discursive opportunities for reflexivity and change (Verloo and Van der Vleuten, 2009). It is in this space that energy and gender advocacy finds some of its traction for making visible and leveraging the linkages between gender equality and successful achievement of energy sustainability.

\section{In conclusion}

Many of the issues raised in our conversations with Joy echo with the experiences of gender practitioners in development settings more broadly. Our discussions around the power of numbers, for example, and the frustrations that accompany a knowledge hierarchy that defines quantitative data as 'evidence' and qualitative data as 'anecdote' is one that would find resonance for many gender researchers, particularly for those attuned to feminist debates around science, objectivity and situatedness (Haraway, 1988). Our starting point, however, was the extent to which the energy sector, which is embedded in engineering practice and the market logics of resource allocation, creates distinctive challenges for addressing gender equality and for the application of gender expertise. Joy's decades-long experience in this field, as a qualified engineer and as a founding member of the influential international research and advocacy network ENERGIA, points to some of the 'wins' - spaces from which change can happen, that she has experienced over the years. She adopts a strategy akin to what Carol Bacchi refers to as strategic reflexivity: enabling her to 'capitalize on small margins for change' (2009: 29).

Three 'small margins' stand out as 'take home' messages from our conversation. First, a common language is made easier where there is some co-recognition of knowledge and expertise between the gender researcher and other expert 
stakeholders. Joy's background as a mechanical engineer enables her to find common ground with technical colleagues. Her own story of how she became attuned to gender differences and inequalities in the energy sector has been instructive for how she brings these concerns to potentially sceptical colleagues (gently and without recourse to university-based feminist theorising). Secondly, whilst historically engineering has been shaped through its embeddedness within corporate and military institutions (Mills et al., 2014), Joy's engagement with this technical field is instead situated within an alternative development paradigm of intermediate (appropriate) technology. Joy makes the point that this branch of engineering has been open to engaging with people, making the step towards embracing gender only a small one. The challenges of finding a common language are perhaps less with an epistemological gap with engineers of appropriate technology, and more with a context where the primary engagement is with policy makers working at scale and in the context of neoliberal development, with all its technologies of $\log$ frames and quantitative impact indicators. Thus, thirdly, Joy and her colleagues have attempted to address this challenge by creating an expert network encompassing a diversity of people, things and ideas in the form of ENERGIA - a network that produces knowledge on gender and energy (through relatively conventional mainstreaming tools such as gender audits) and makes it effective in the world through advocacy work.

However, as some of our other contributors have outlined, whilst the situated everyday practices that make up Joy's work with ENERGIA have opened up room for manoeuvre, by far the most important factor in enabling gender to be a key part of energy and development work is the convergence of the SDGs (and their global tracking) and the impetus for energy transformation to address climate change. The performativity of each of these makes it all the more important that the right kinds of gender work materialise, and that these do not go on to constitute another trap or burden for the disadvantaged.

\section{References}

Azocar, M. J., \& Ferree, M. M. (2016). Engendering the sociology of expertise. Sociology Compass, 10(12), 1079-1089. https://doi.org/10.1111/soc4.12438

Bacchi, C. (2009). The issue of intentionality in frame theory: The need for reflexive framing. In M. Verloo, P. Meier, \& E. Lombardo (Eds.), The Discursive Politics of Gender Equality: Stretching, Bending and Policy-Making (pp. 30-41). London: Routledge.

Caglar, G., Prügl, E., \& Zwingel, S. (2013). Introducing feminist strategies in international governance. In G. Caglar, E. Prügl, \& S. Zwingel (Eds.), Feminist Strategies in International Governance (pp. 1-18). Oxon, UK: Routledge.

Cecelski, E. W. (1995). From Rio to Beijing. Engendering the energy debate. Energy Policy, 23(6), 561.

Cecelski, E. (2004). Re-thinking Gender and Energy: Old and New Directions. ENERGIA/ EASE.

Cecelski, E., \& CRGGE, (the Collaborative Research Group on Gender and Energy). (2006). From the Millennium Development Goals Towards a Gender-Sensitive Energy 
Policy Research and Practice: Empirical Evidence and Case Studies-Synthesis Report. The Hague: ENERGIA.

Cecelski, E., \& Dutta, S. (2011). Mainstreaming Gender in Energy Projects: A Practical Handbook. Resource Pack. Retrieved from ENERGIA website: http://genderandenvi ronment.org/resource/mainstreaming-gender-in-energy-projects-a-practical-handboo k-resource-pack/

Clancy, J. (2016). Transforming energy systems and gender roles and relations are interconnected. Inaugural lecture Joy Clancy. Available online from ENERGIA.ORG. https://www.energia.org/?s=Joy+Clancy

Clancy, J. S., Skutsch, M., \& Batchelor, S. (2002). The Gender-Energy-Poverty Nexus: Finding the Energy to Address Gender Concerns in Development (No. DFID Project CNTR998521). Retrieved from DFID website: https://research.utwente.nl/en/publicati ons/the-gender-energy-poverty-nexus-finding-the-energy-to-address-gen

Connell, R. (2016). Masculinities in global perspective: Hegemony, contestation, and changing structures of power. Theory and Society, 45(4), 303-318.

Danielsen, K. (2012). Gender Equality, Women's Rights and Access to Energy Services . An Inspiration Paper in the Run-up to Rio+20. Amsterdam: Royal Tropical Institute (KIT).

de Groot, J., Mohlakoana, N., Knox A, \& Bressers, H. (2017). Fuelling women's empowerment? An exploration of the linkages between gender, entrepreneurship and access to energy in the informal food sector. Energy Research \& Social Science, 28, 86-97

ENERGIA. (2015). Mainstreaming gender in energy projects. ENERGIA International Network on Gender and Sustainable Energy. http://energia.org/wpcontent/uploads/201 5/02/01.-Mainstreaming_gender_in_energy_projects_A_practical_Hand_book.pdf

Ettinger, L., Conroy, N., \& Barr II, W. (2019). What late-career and retired women engineers tell us: gender challenges in historical context. Engineering Studies, 11(3), 217-242

Eyben, R. (2010). Subversively accommodating: feminist bureaucrats and gender mainstreaming. IDS Bulletin, 41(2). https://doi.org/10.1111/j.1759-5436.2010.00123.x

Eyben, R., \& Turquet, L. (Eds.). (2013). Feminists in Development Organizations: Change from the Margins. Rugby: Practical Action Publishing.

Faulkner, W. (2009a). Doing gender in engineering workplace cultures. I. Observations from the field. Engineering Studies, 1(1), 3-18. https://doi.org/10.1080/19378620902 721322

Faulkner, W. (2009b). Doing gender in engineering workplace cultures. II. Gender in/ authenticity and the in/visibility paradox. Engineering Studies, 1(3), 169-189. https:// doi.org/10.1080/19378620903225059

Gay-Antaki, M. (2016). 'Now we have equality': A feminist political ecology analysis of carbon markets in Oaxaca, Mexico. Journal of Latin American Geography, 15(3), 49-66.

Haraway, D. (1988). Situated knowledges: The science question in feminism and the privilege of partial perspective. Feminist Studies, 14(3), 575-599.

IEA (International Energy Agency). (2019). Tracking SDG7: The Energy Progress Report. https://trackingsdg7.esmap.org/

Jasanoff, S. (2004). States of Knowledge: The Co-Production of Science and Social Order. Routledge.

Kabeer, N. (2016). Gender equality, economic growth, and women's agency: the 'endless variety' and 'monotonous similarity' of patriarchal constraints. Feminist Economics, 22(1), 295-321. 
Kelkar, G., \& Nathan, D. (2005). Gender Relations and the Energy Transition in Rural Asia. Retrieved from Collaborative Research Group on Gender and Energy (CRGGE) with support from the ENERGIA International Network on Gender and Sustainable Energy website: https://www.gov.uk/dfid-research-outputs/gender-relations-and-the -energy-transition-in-rural-asia

Kooijman, A., Cloke, J., \& Clancy, J. (2018). Needs, wants and values: Integrating gender with energy access. Briefing paper 3. Low Carbon Energy for Development Network and ENERGIA. December 2018. https://www.energia.org/cm2/wp-content/ uploads/2019/03/Final-Gender_Low-Carbon-Energy-Network-Briefing-Paper-3-AWweb.pdf

Kronsell, A. (2011). Gendered practices in institutions of hegemonic masculinity. International Feminist Journal of Politics, 7(2): 280-298.

Lambrou, Y., \& Piana, G. (2006). Energy and Gender Issues in Rural Sustainable Development. Rome: FAO.

Latour, B. (1987). Science in Action: How to Follow Scientists and Engineers through Society. Boston, MA: Harvard University Press.

Leach, M., Scoones, I., \& Stirling, A. (2010). Dynamic Sustainabilities: Technology, Environment, Social Justice. London: Earthscan.

Liebrand, J. (2014). Masculinities among Irrigation Engineers and Water Professionals in Nepal (Wageningen University). http://edepot.wur.n1/321002

Matinga, M. N. (2010). 'We Grow Up With It': An Ethnographic Study of the Experiences, Perceptions and Responses to the Health Impacts of Energy Acquisition and Use in Rural South Africa. PhD Thesis, University of Twente, Enschede, The Netherlands.

Miller, C. A., Richter, J., \& O’Leary, J. (2015). Socio-energy systems design: A policy framework for energy transitions. Energy Research \& Social Science, 6, 29-40.

Mills, J.E., Franzway, S., Gill, J. and Sharp, R. (2014). Challenging Knowledge, Sex and Power: Gender, Work and Engineering. London: Routledge.

Milner, T. (2017) From Intermediate Technology to Technology Justice: The Knowledge Sharing Journey of Practical Action https://www.theimpactinitiative.net/impact-lab/ collection/intermediate-technology-technology-justice

Nelson, S., \& Kuriakose, A. T. (2017). Gender and Renewable Energy: Entry Points for Women's Livelihoods and Employment. Climate Investment Funds.

Nightingale, A. J., Eriksen, S., Taylor, M., Forsyth, T., Pelling, M., Newsham, A., ... Whitfield, S. (2019). Beyond technical fixes: climate solutions and the great derangement. Climate and Development, 1-10. https://doi.org/10.1080/17565529.20 19.1624495

Pearl-Martinez, R., \& Stephens, J. C. (2016). Toward a gender diverse workforce in the renewable energy transition. Sustainability: Science, Practice, \& Policy, 12(1). http:// search.proquest.com/openview/33f4fc69af7b9886ecea63b4565af3d1/1?pq-origsite $=$ gs cholar\&cbl=136137

Practical Action (n.d.). Who we are and what we do. https://practicalaction.org/who-we-are/

Rathgeber, E. M. (1990). WID, WAD, GAD: trends in research and practice. The Journal of Developing Areas, 24(4), 489-502.

Razavi, S. (1997). Fitting gender into development institutions. World Development, 25(7), 1111-1125. https://doi.org/10.1016/S0305-750X(97)00023-5

Razavi, S. (2017). Revisiting equity and efficiency arguments for gender equality: A principled but pragmatic approach. Canadian Journal of Development Studies/Revue Canadienne d'études du Développement, 38(4), 558-563. https://doi.org/10.1080/0 2255189.2017.1376624 
Rojas, A. V., Schmitt, F. M., \& Aguilar, L. (2014). Guidelines on Renewable Energy Technologies for Women in Rural and Informal Urban Areas. Retrieved from IUCN and ENERGIA website: http://genderandenvironment.org/resource/guidelines-onrenewable-energy-technologies-for-women-in-rural-and-informal-urban-areas/

Saks, M. (2012). Defining a profession: The role of knowledge and expertise. Professions and Professionalism, 2(1). https://doi.org/10.7577/pp.v2i1.151

Sandler, J., \& Rao, A. (2012). Strategies of Feminist Bureaucrats: United Nations Experiences (Working Paper No. 397). Sussex, UK: Institute of Development Studies.

Tuana, N. (2013). Gendering climate knowledge for justice: catalyzing a new research agenda. In M. Alston \& K. Whittenbury (Eds.), Research, Action and Policy: Addressing the Gendered Impacts of Climate Change (pp. 17-31). Dordrecht: Springer Netherlands.

Verloo, M., \& Van der Vleuten, A. (2009). The discursive logic of ranking and benchmarking Understanding gender equality measures in the European Union. In P. Meier, E. Lombardo, \& M. Verloo (Eds.), The Discursive Politics of Gender Equality: Stretching, Bending and Policy-Making (pp. 169-185). London: Routledge. 